\title{
Gençlerin Psikolojik İhtiyaçları Nelerdir?
}

\author{
DOI: 10.26466/opus.395945
}

\section{Cağgla Girgin-Büyükbayraktar- Hasan Bozgeyikli* ${ }^{* *}$ Şahin Kesici***}

* Dr. Öğr. Ü., Selçuk Üni. Ali Akkanat Uygulamalı Bilimler Yüksek Okulu, Beyşehir / Türkiye

\author{
E-Posta: cagla.girgin@hotmail.com ORCID: 0000-0001-8440-6320 \\ ${ }^{* *}$ Doç. Dr. Erciyes Üniversitesi, Eğitim Fakültesi, Kayseri / Türkiye
}

E-Posta: hbozgeyikli@erciyes.edu.tr ORCID: 0000-0002-6762-1990

***Prof. Dr. Necmettin Erbakan Üniversitesi, Ahmet Keleşoğlu Eğitim Fakültesi, Konya / Türkiye E-Posta: sahinkesici@konya.edu.tr $\quad$ ORCID: $\underline{0000-0003-3823-5385}$

Öz

Bu araştırmanın amacı, üniversite öğrencilerinin psikolojik ihtiyaçlarını belirlemektir. Bu çalışmada nitel araştırma tekniği kullanılmıştır. Araştırma için amaçlı örnekleme yönteminden yararlanılmıştır. Araştırmaya psikolojik danışma servisine başvuran üniversite öğrencileri katılmıştır. Araştırmanın çalışma grubu 43 üniversite öğrencisinden oluşmaktadır. Bu üniversite öğrencilerinin 25'i kadın (\%58.14), 18'i (\%41.87) erkektir. Yaşlarma göre öğrenciler 18-20 yaş aralığında 21 kişi (\%48.84), 21-23 yaş aralığında 12 kişi (\%27.90), 24-26 yaş aralığında 7 kişi (\%16.28) ve 26 yaş ve üzerinde 3 kişi (\%6.98) olarak dağıllım göstermektedirler. Devam ettikleri sınıf değişkenine göre öğrencilerin dağılımı 1.sınıfa devam edenler 8 kişi (\%18.60), 2.sınıfa devam edenler 12 kişi (\%27.90), 3.sınıfa devam edenler 16 kişi (\%37.22) ve 4.sınıfa devam edenler 7 (\%16.28) kişidir. Araştırma verilerinin toplanmasında veri toplama yöntemi olarak yar yapılandırılmış görüşme tekniği kullanılmıştır. Görüşme sonucu elde edilen veriler, içerik analizi tekniği ile analiz edilmiştir. Veriler yorumlanırken psikolojik ihtiyaçlar teması ile ilgili kategoriler oluşturulmuştur. Araştırmada uygulanan yarı yapılandırılmış görüşme formundan elde edilen verilerin içerik analizi ile elde edilen sonuçlarında, üniversite öğrencisi gençlerin psikolojik ihtiyaçlarında; toplumsal statü, başarma, yeterlilik, ait olma ve ilgi görme ihtiyaçlarının önem kazandığı ortaya konulmuştur.

Anahtar Kelimeler: Gençler, Görüşler, Psikolojik ihtiyaç

OPUS (c) Uluslararası Toplum Araştırmaları Dergisi-International Journal of Society Researches ISSN:2528-9527 E-ISSN : 2528-9535

http://opusjournal.net 


\title{
What are the Psychological Needs of the Youth?
}

\begin{abstract}
The purpose of this research is to determine the psychological needs of university students. Qualitative research technique was used in this study. Purposive sampling method was used for the research. University students who applied to the psychological counseling service participated in the research. The study group of the research consists of 43 university students. 25 (58.14\%) of these university students are female and $18(41.87 \%)$ are male. According to their ages, the students range as 21 persons (48.84\%) in the age range of 18-20 years, 12 persons $(27.90 \%)$ in the age range of 21-23 years, 7 persons (\% 16.28) in the age range of 24-26 years, and 3 persons (6.98\%) 26 years and over. The distribution of students according to the class variable they attend is that the ones who continue to the 1 st class are 8 persons $(18.60 \%), 12$ persons in the second class $(27.90 \%), 16$ persons $(37.22 \%)$ in the third class and $7(16.28 \%)$ persons in the fourth class. Semistructured interview technique was used as data collection method in collecting research data. The data obtained after the interview was analyzed by content analysis technique. While the data was interpreted, categories related to psychological needs were formed. In the results obtained by content analysis of the data through the semi-structured interview form applied in the research, their needs of social status, achievement, order, competence, sense of belonging and getting attention were proven to be important in psychological needs of young university students.
\end{abstract}

Anahtar Kelimeler: Youth, Opinions, Psychological needs

OPUS (c) Uluslararası Toplum Araştırmaları Dergisi-International Journal of Society Researches ISSN:2528-9527 E-ISSN : 2528-9535

http://opusjournal.net 


\section{Giriş}

Çocukluk ve yetişkinlik arasında bir geçiş evresi olan "gençlik"; Erikson (1968)'a göre geç ergenlik olarak tanımlanmaktadır, yani bu yaş yetişkinlikten daha önceki dönemi ifade eder. Gençlik ergenlikle benzer özellikler taşır ve onun devamı niteliğindedir. Bedensel büyüme hızla devam eder. Büyüyen ve gelişen genç psikolojik bir yenilenme ile karşı karşıya kalır. Aynı zamanda gençten somut yetişkin görevlerini yerine getirmesi beklenir (Erikson, 1977, s. 235). 18-26 yaş aralığına denk gelen bu dönem genç yetişkinlik dönemi olarak da adlandırılır (Senemoğlu, 2005, s. 79). Bu dönem bireyin aynı cinsten olan ya da olmayan insanlarla yakın ilişkiler kurabilmesini gerektirir (Can, 2009, s. 133). Genç yakınlığa karşı uzaklık döneminde başkaları ile yakın ilişkiler kurabilme yeteneğini kazanmış olmalıdır. Genç bu yeteneği kazanmış ise karşı cinsle ve hem cinsleriyle iyi ilişkiler kurabilir (Erden ve Akman, 2004, s. 99; Güngör, 2006).

Gençlik insanın çocukluktan çıkıp olgunluğa doğru yürüdüğü bir çağdır (Özkan, 1987). Gençlik gibi, insanın en dinamik, döneminin ele alınması, gençliğin enerjisinden faydalanılması belkide incsanlık adına önemli bir görevdir. Bu açıdan gençlik, bütün sosyolojik kurumların üzerinde durduğu ve ilgi alanını oluşturan bir popülasyondur (Tuncay, 2000). Toplumların geleceğini yakından ilgilendiren nüfusun en dinamik kesimi olarak gençler tüm insanlık tarihi boyunca toplumların gelişmesinde önemli rol oynamıştır (APK, 2004, s. 17). Gençler kendi gelişmelerinin üreticisidirler; yetişkinler genç insanların içindeki olumlu potansiyelleri destekledikleri zaman daha fazla etkili olurlar (Larson, 2006).

Bireylerin ihtiyaçlarını bilim adamları çeşitli bakış açılarıyla ele almışlardır(Kesici, 2008a). Pek çok psikolog temel ihtiyaçlar söz konusu olduğunda bütün motivasyonların zevk temeline dayandığına inanır. Örneğin aç olan bir kişi, açlı̆̆ın oluşturduğu gerginliği azaltmak için yemek yer. Tüm insan davranışları zevkle ilişkilendirilebilir (Strickland, 2001, s. 196). Genellikle, literatür gözden geçirildiğinde, temel ihtiyaçlar teriminin tipik olarak insanoğlunun yiyecek, barınak, giysi, hava ve su için sahip olduğu ihtiyaç, diğer bir deyişle fiziksel hayatta kalma için temel ihtiyaçlar, anlamına geldiği düşünülmektedir. Bununla birlikte, 
pek az kişi temel ihtiyaçlar kavramını hayatta kalma seviyesinin ötesine genişletir (Litwack, 2007).

İhtiyaçlar konusunda önemli bir kuramcı olan Maslow'a göre insanlar yeteneklerini ve temel ihtiyaçlarını karşılayabilmek için biyolojik olarak belirlenmiş içsel kapasitelere sahiptirler (Maslow, 1954). Maslow güdüsel ihtiyaçları bir hiyerarşi içine yerleştirir ve daha karmaşık yüksek düzeydeki ihtiyaçlar karşılaşmadan önce belirli temel ihtiyaçların karşılanması gerektiğini idda eder (Maslow, 1954). Maslow'un en düşük ve en basitten en yüksek ve en karmaşığa doğru sıralanan beş ihtiyacı vardır; fizyolojik ihtiyaçlar; emniyet ve güvenlik ihtiyaçları, sevgi ve aidiyet ihtiyaçları, saygı ihtiyacı ve kendini gerçekleştirme ihtiyacı olmak üzere (Maslow, 1968).

Temel psikolojik ihtiyaçlar bir kişinin hedeflerine ulaşabilmesi ve işlevini en iyi şekilde yerine getirmesi için motivasyon sağlayan üç ihtiyaçtan oluşur (Ryan ve Deci, 2000; Ryan ve Deci, 2006). Özerk benlik yönetimi kuramına göre bireysel gelişim özerklik, yeterlilik ve ilişkililiği de içeren üç temel ihtiyacı çevrenin destekleyip desteklemediğine dayalı olarak değişir (Deci ve Ryan, 2008). Özerklik bir kişinin kendi seçimleri ve kararları üzerindeki içsel olarak algılanan kontrol olarak tanımlanır. Yeterlilik, bir görevi etkili bir şekilde tamamlayabilme kabiliyetini hissetme anlamına gelir. İlişkililik başkalarına ilişkin güven duygusunu ve birinin toplumsal çevreye ait olma duygusunu içerir (Ryan ve Deci, 2000; Deci, Ryan, Gagné, Leone, Usitnov ve Kornazheva, 2001; Baumeister ve Leary, 1995). Bu kurama göre bu üç psikolojik ihtiyaç evrenseldir (Brenning ve Soenens, 2017) doğuştan gelir ve biyolojik ihtiyaçlar gibi zorunludur (Jang, Reeve, Ryan ve Kim, 2009; Deci ve Vansteenkiste, 2004; Ryan ve Deci, 2000).

İhtiyaçlarla ilgili bir diğer kuram olan Csikszentmihalyi'nin "akış" teorisi, yetkinlik ihtiyacının önemini vurgulamaktadır; akış (kavramsal olarak içsel motivasyona benzer); görev kişinin beceri seviyesi ile iyi dengelenmiş olduğunda yani görev ne çok zor ne de çok kolay ise kişi kendi becerisini değerlendirmek için bilgiye sahip olur. Kişi görevden ne sıkılmıştır ne de sinir hisseder, bunun yerine zaman içinde biriken küçük yetenek deneyimlerinden oluşan sürekli bir akış elde eder (Csikszentmihalyi, 1990). 
McClelland (1985)'ın öğrenilmiş ihtiyaç teorisi ihtiyaçları anlamak için geliştirilmiş bir yaklaşımdır. Bu yaklaşıma göre temel ihtiyaçlar zamanla edinilmiş, kişinin yaşam deneyimleri ile şekillenmiş (Atkinson, 1957), nispeten zaman içinde kalıcı hale gelmiş, kişiden kişiye farklılık göstermesi ile kavramsallaştırılmıştır. McClelland teorisine göre, insanlar belirli bir hedefe ulaştıktan sonra takdir edildiklerinde, bu gibi durumlarla olumlu duyguları eşleştirirler ve bunu öğrenirler, bu duyguyu yeniden yaşama ihtiyacı duyarlar. McClelland, Atkinson, Clark ve Lowell (1953)'in araştırmalarındaki ihtiyaçlar başarı, yakın ilişki ve güç ihtiyacı olarak sınıflandırılabilir.

Murray (1938) kişilik teorisinde tüm insanların temel ihtiyaçlara sahip olduğuna inanmaktadır, fakat ihtiyaçların önemi konusunda bireysel farklılıklar vardır. Murray ihtiyaçları içsel-temel (örneğin, yiyecek, su, cinsellik, boşaltım gibi) ve psikolojik-ikincil olmak üzere sınıflandırmıştır. Murray 20 adet psikolojik ihtiyaç belirlemiştir. Bunlardan bazıları olumludur, ihtiyaçlara yakınlaşmayı gerektirir, bazıları da olumsuzdur, ihtiyaçlardan kaçınmayı gerektirir. Murray aynı zamanda bazı durumlarda birkaç ihtiyacın bir araya gelerek davranışı yönlendirebileceğini ve bazı ihtiyaçlarında birbirleriyle çatışabileceğine inanmaktadır (Murray, 1938).

Gençlerin yalnızca bilgiye değil aynı zamanda uygulama için fırsat bulmaya da ihtiyaçları vardır. Bu noktada okullara, toplumsal programlara ve medyaya büyük görev düşmektedir (McLeod, 2000). Buradan hareketle gençlerin ihtiyaçlarının belirlenip bu doğrultuda ilerlenmesi gerekecektir. İşte bu noktadan yola çıkarak bu çalışmanın amacl; üniversite öğrencilerinin psikolojik ihtiyaçlarını belirlemektir. Bu amaç doğrultusunda aşağıdaki soruya yanıt aranmıştır.

1-Psikolojik ihtiyaçlarınızı nelerdir, lütfen ayrıntılı olarak belirtiniz? 


\section{Yöntem}

\section{Araştırmanın Modeli}

Bu çalışmada nitel araştırma tekniği kullanılmıştır. Nitel araştırma özellikle neden, ne veya nasil sorularına yanit arar (Lacey ve Luff, 2007). Nitel araştırma belirli bir alandaki tanımlayıcı anlamlı kalıpları keşfetmek amaciyla metinleri analiz etmeyi ve yorumlamayı gerektirir (Auerbachand ve Silverstein, 2003). Bu araştırmada amaç araştırmaya konu olan bireylerin olaylara, deneyimlere ve problemlere yükledikleri anlamları ortaya çıkarmaktır (Güler, Halıcıoğlu ve Taşğın, 2015). Nitel veriler, genellikle sayılar yerine kelimeler biçiminde ifade edilir (Miles ve $\mathrm{Hu}$ berman, 1994).

\section{Çalışma Grubu}

Araştırmada kullanılan örnekleme yöntemi amaçlı örneklemedir. Nitel araştırmalarda en fazla kullanılan örnekleme yöntemi olasılıklı olmayan örneklemedir.Başlıca olasılıklı olmayan örnekleme türlerinden biri de amaca yönelik örneklemedir. Amaca yönelik örneklemede araştırmacı önce evrendeki varyasyonlardan ilgilendiği bir tanesini belirler, daha sonra bu varyasyonu yansitacak bir örneklem seçer (Güler, Halıcıŏlu ve Taşğın, 2015). Katılımcı seçim kriteri çalışmaya gönüllü olarak katılmak isteyen üniversitenin psikolojik danışma servisine başvuran öğrenciler üzerinde yapılmasıdır. Araştırmanın çalışma grubu 43 üniversite öğrencisinden oluşmaktadır. Bu üniversite öğrencilerinin 25'i kadın (\%58.14), 18 'i (\%41.87) erkektir. Yaşlarına göre öğrenciler 18-20 yaş aralığında 21 kişi (\%48.84), 21-23 yaş aralığında 12 kişi (\%27.90), 24-26 yaş aralığında 7 kişi (\%16.28) ve 26 yaş ve üzerinde 3 kişi (\%6.98) olarak dağ 1 lım göstermektedirler. Devam ettikleri sınıf değişkenine göre öğrencilerin dağılımı 1.sınıfa devam edenler 8 kişi (\%18.60), 2.sınıfa devam edenler 12 kişi (\%27.90), 3.sınıfa devam edenler 16 kişi (\%37.22) ve 4.sınıfa devam edenler 7 (\%16.28) kişidir. 


\section{Yarı Yapılandırılmış Görüşme Tekniği}

Çalışmada verilerin toplanması sırasında yarı yapılandırılmış görüşme tekniğinden yararlanılmıştır. Nitel araştırmalarda yaygın olarak kullanılan bir veri toplama yöntemi olan yarı yapılandırılmış görüşme araştırmacı tarafından önceden belirlenmiş ya da görüşme sırasında ortaya çıkan konulara göre yeni soruların da sorulabildiği bir görüşme yöntemidir (Aziz, 1994; Ekiz, 2017; Güler, Halıcıoğlu ve Taşğın, 2015). Gençlerin psikolojik ihtiyaçları litaretür taramasında göz önünde bulundurulmuştur.Yarı yapılandırılmış görüşme formu geliştirilerek gençlerin psikolojik ihtiyaçları tespit edilmeye çalışılmıştır.Görüşme formu NEÜ'den altı öğretim üyesinin görüşlerinden faydalanılarak oluşturulmuştur. Görüşmelerde not alma yöntemi vasıtasıyla veriler kayıt edilmiştir (Yıldırım ve Şimşek, 2005). Araştırmanın araştııılan kişileri ya da durumları yansıtan çoğu kez de araştırılan kişilerin vermeye çalıştıkları anlamları onların kullandıkları kelimeler ve yorumlamaların ortaya konması yorumlayıcı geçerlik olarak adlandırılır. Bu özellik araştırmanın bütün gerçekliği ile ortaya konabilmesi ile ilişkilidir (Ekiz, 2017).

\section{Verilerin Toplanması}

Veriler toplanırken katılımcıların çalışmaya gönüllü olarak katılmalarına dikkat edilmiştir. Katılımcılar için bir açılama formu hazırlanmış ve burada çalışmanın amacına, nasıl gerçekleştirileceğine katılımcıların anlayabileceği şekilde yer verilmiştir. Çalışmaya katılanların kimliklerinin gizli kalacağ1 konusunda kişilere güven verilmiştir. Görüşmelerde yazılı görüşme formundan yararlanılmıştır. Katılımcıların sorulara cevap verme süreleri 10-15 dakika arasındadır.

\section{Verilerin Analizi ve Yorumlanması}

Verilerin analizinde içerik analizinden yararlanılmıştır. İçerik analizi metin veya metinlerden oluşan bir kümenin içindeki belli kelimelerin veya kavramların varlığını belirlemeye yönelik yapılır. Araştırmacı bu kelime ve kavramların varlığını, anlamlarını ve ilişkilerini belirler ve 
analiz ederek metindeki mesaja ilişkin çıkarımlarda bulunur. İçerik analizinde birbirleri ile ilişkili veriler kavram ve temalar olarak organize edilir. Bu esnada kategori ve alt kategoriler halinde veriler analiz edilir (Büyüköztürk, Kılıç-Çakmak, Akgün, Karadeniz ve Demirel, 2008; Ekiz, 2017).

Veriler yarı yapılandırılmış formlar aracılığı ile toplanmıştır. Herbir form birden başlayarak numaralandırılmıştır. İçerik analizde veriler sinıflara ayrılır (kategori) ve alt-üst sınıflamalar yapılabilir. Bunlar arasındaki ilişkiyi göstermek için matris hazırlanmalıdır. Bu sınıflamalar sayısal verilere dönüştürülebilir. Bu veriler üzerinde nitel veri analizi programlarıyla bilgisayarda gerekli işlemler yapılabilir (Sönmez ve Alacapınar, 2017). Bu sinıflama yapılırken "bilgisayar destekli nitel veri analiz programı olan Nvivo7" den faydalanılmıştır.

\section{Bulgular}

Üniversite öğrencilerinin psikolojik ihtiyaçlarının neler olduğu ile ilgili kendi görüşleri analiz edilmiş, görüşler doğrultusunda psikolojik ihtiyaçlar teması içinde verilen cevaplar kategorilere ayrılmıştır. Psikolojik ihtiyaçlar teması ile ilişkili kategoriler, kategoriler ile ilgili öğrencilerin görüşleri ve kişi sayısı Tablo 1'de yer almaktadır.

\section{Psikolojik İhtiyaçlar Teması}

Gençlerin psikolojik ihtiyaçları kendi görüşlerine göre analiz edilmiş ve psikolojik ihtiyaçlar teması altında 11 kategori belirlenmiştir. Bu kategoriler; toplumsal statü (22 kişi), ait olma (20 kişi), ilgi görme (17 kişi), başarma (15 kişi), yeterlilik (12 kişi), sevgi (10 kişi $)$, kendini gerçekleştirme (9 kişi), özgürlük/özerklik (8 kişi), duyguları anlama (5 kişi), eğlence/serbest zaman faaliyetine olanak verme (4 kişi), düzen (3 kişi) olarak sıralanmaktadır. 
Tablo 1. Gençlerin Psikolojik İhtiyaçlarına Yönelik Görüşleri

\begin{tabular}{|c|c|c|c|}
\hline Tema & $\begin{array}{l}\text { Kate- } \\
\text { goriler }\end{array}$ & $\begin{array}{l}\text { Kate- } \\
\text { gorilere } \\
\text { Katılan } \\
\text { Öğrenci } \\
\text { Sayısı }\end{array}$ & Öğrenci Görüşlerinden Örnekler \\
\hline \multirow{8}{*}{ 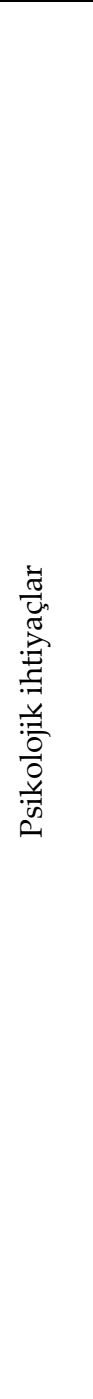 } & $\begin{array}{l}1- \\
\text { Toplumsal } \\
\text { Statü }\end{array}$ & 22 & $\begin{array}{l}\text { "Değer görme, saygin bir iş ortamının olmass } \\
\text { benim psikolojik ihtiyaçlarım sayllabilir." } \\
\text { (Ö2'in görüşü) }\end{array}$ \\
\hline & 2-Başarma & 15 & $\begin{array}{l}\text { "Sanırım en önemli psikolojik ihtiyacım başarı. } \\
\text { Yaptığım işin en iyisini yapmak, o işte uzman } \\
\text { olmak isterim. Başarılı olamayacağım bir işe } \\
\text { hiç başlamam." (Ö8'in görüşü) } \\
\text { "Girdiğim her sinavı başarıyla geçmek temel } \\
\text { amacımdır."(Ö7'nin görüüü) }\end{array}$ \\
\hline & 3-Sevgi & 10 & $\begin{array}{l}\text { "Benim için hayatta sevmek ve sevilmekten } \\
\text { daha önemli birşey yoktur."(Ö21'in görüşü) }\end{array}$ \\
\hline & $\begin{array}{l}\text { 4-Kendini } \\
\text { gerçekleşti } \\
\text { rme }\end{array}$ & 9 & $\begin{array}{l}\text { "Hayatımın geri kalanında kendi hayallerimi, } \\
\text { isteklerimi gerçekleştirmek birinci öncelik } \\
\text { olacaktır. Kendi ilgilendiğim alanda, zevkle } \\
\text { yapabileceğim uğraşlar." (Ö12'nin görüşü) }\end{array}$ \\
\hline & $\begin{array}{l}5- \\
\text { Eğlence/Se } \\
\text { rbest za- } \\
\text { man faali- } \\
\text { yetine } \\
\text { olanak } \\
\text { verme }\end{array}$ & 4 & $\begin{array}{l}\text { "Boş zamanlarımda kitap okumayı, gazete- } \\
\text { dergi okumayı, çocuğumla oynamayı, medita- } \\
\text { syon yapmayı seviyorum. Bunlar beni rahat- } \\
\text { latıyor. Eşimle, çocuğumla, ailemle, komşu- } \\
\text { larımla, işyerindekilerle açık ve iyi iletişim } \\
\text { kurmaya çalışıyorum." (Ö10'un görüşü) } \\
\text { "Boş zamanlarımı yapmaktan hoşlandığım } \\
\text { işleri yaparak geçirmek benim önemli bir ih- } \\
\text { tiyacım"(Ö1'in görüşü) }\end{array}$ \\
\hline & $\begin{array}{l}\text { 6- } \\
\text { Özgürlük/ } \\
\text { Özerklik }\end{array}$ & 8 & $\begin{array}{l}\text { "Hayatta kimsenin işime karışmadığı özgür } \\
\text { kararlar alabildiğim bir ortamda yaşamak } \\
\text { isterim."(Ö25'in görüşü) }\end{array}$ \\
\hline & 7-Düzen & 3 & $\begin{array}{l}\text { "İşlerimin planlı ve düzenli olması benim için } \\
\text { önemlidir."(Ö18'in görüşü̈) }\end{array}$ \\
\hline & 8-Yeterlilik & 12 & $\begin{array}{l}\text { "Etrafımdaki insanlarla } \\
\text { severim." (Ö15' in görüşü) }\end{array}$ \\
\hline
\end{tabular}




\begin{tabular}{|l|l|l|l|}
\hline & 20 & $\begin{array}{l}\text { "Bir yere gittiğimde ya da bir iş yaptığımda bir } \\
\text { grubun üyesi olduğumda kendimi daha iyi } \\
\text { hissediyorum."(Ö31'in görüşü) }\end{array}$ \\
\cline { 2 - 4 } & $\begin{array}{l}\text { 9-Ait olma } \\
\text { Duyguları } \\
\text { Anlama }\end{array}$ & 5 & $\begin{array}{l}\text { “İnsanların ne hissettikleri ile ilgileni- } \\
\text { rim."(Ö29'un görüşü) }\end{array}$ \\
\hline $\begin{array}{l}11-\text {-̇̈lgi } \\
\text { görme }\end{array}$ & 17 & $\begin{array}{l}\text { "Başkaları tarafından ihtiyaçlarımın sorulması } \\
\text { ve bana ilgi göstermeleri başlıca ihtiyacım olan } \\
\text { şeylerden."(Ö3'ün görüşü) }\end{array}$ \\
\hline
\end{tabular}

\section{Tartıșma}

Varlıklarını ve gelişimlerini sürdürebilmek için bireylerin bazı temel ihtiyaçları karşılanmalıdır (Bozgeyikli, 2010). Sevgi, inanç, güven, girişim, bağımsızlık gibi psikolojik ihtiyaçları gence hayatının ilk yıllarında yol gösterir (Özkan, 1987).

Gençlerin psikolojik ihtiyaçları incelendiğinde gençlerden alınan cevaplar doğrultusunda toplumsal statü (22 kişi), ait olma (20 kişi), ilgi görme (17 kişi), başarma (15 kişi) ve yeterlilik (12 kişi) ihtiyaçlarının gençler tarafından daha fazla önemsendiği görülmektedir. İnsan bazı grupların üyesi olmak ve bazı statüleri işgal etmekle, bir aidiyet duygusu taşımaktadır ve ayrıca bireyin kendisini topluma kabul ettirmesi, popülerlik ve tanınmış olma isteği iyi oluş halini de olumlu etkilemekte (Ceylan, 2011; Sheldon, Ryan, Deci ve Kasser, 2004). Buradan hareketle gençlerin toplumsal statü elde etme ihtiyacı onay arama ve toplumda bir yer elde etmek istemelerinden kaynaklanıyor olabilir. Gençler toplumsal statü elde etmek istiyor ve daha çok çabalıyor olamalarının nedeni toplumda statü sahibi insanların daha çok rabet görüyor olmaları olarak düşünülebilir.

Kişinin kendisi ve kendisi için önemli olan bireyler tarafından sevildiğini ya da sosyal bir gruba ait olduğunu hissetmesine aidiyet denir (Vlachopoulos ve Michailidou, 2006; Kowal ve Fortier, 1999). Genç öncelikle bir aileye ait olma daha sonra bir meslek grubuna ait olma ve yakın çevreye ait olma ihtiyacı içindedir (Kesici, 2008b; Kesici, 2007; Kesici, 2015). Bu açıdan bakıldığında ait olma ihtiyacı bireyin duygusal olarak 
kendini bağlı hissetmesine ve diğer insanlarla ilişki kurup bu ilişkiyi sürdürmesine yardımcı olmaktadır (Erwin, 2003).

Murray (1938)'e göre ilgi görme başka bireyler tarafından sevilmek, desteklenmek ve ihtiyaçlarının giderilmesi olarak tanımlanmıştır. Young, Klosko ve Weishaar (2003)'a göre duygusal yoksunluk şeması duygusal destek ihtiyacını başkaları tarafından karşılayamayan bireyleri içine alır. Buradan hareketle gençlerin ilgi görme ihtiyaçları duygusal yoksunluklarını gidermek için takdir edilmek istemelerinden kaynaklaniyor olabilir.

Insanlar kendi kapasitelerini ortaya koymak için başarmak ve üretmek isterler (Kesici, 2008b). Başarı ihtiyacı bir kişiye başarıya ulaşabilmek için zorluklarla yüzleşme gücü verir (Sagie ve Elizur, 1999). Araştırmada ortaya çıan sonuçla parallel olarak gençlerin başarı ihtiyaçları üzerinde duran çalışmalar mevcuttur (Avc1, Bozgeyikli ve Kesici, 2017; Doğan ve Kesici, 2015).

Yeterlik, bir insanın içinde bulunduğu ortamı keşfetmesi, öğrenmesi,ona uyum sağlamasının sonucunda yaşanan üstünlük hissidir (Filak ve Sheldon, 2003). Gencin kendini yeterli hissetmesi için yakın arkadaşlık ilişkilerinin de önemi vardır (Buhrmester, 1990). Bu nedenle gençlerin gerek içsel olarak gerekse sosyal çevrede kendini yeterli olarak alg1lamaları önemli bir ihtiyaçtır denilebilir.

\section{Sonuç}

Gençlerin psikolojik ihtiyaçları incelendiğinde toplumsal statü (22 kişi), ait olma (20 kişi), ilgi görme (17 kişi) ve başarma (15 kişi) ve yeterlilik (12 kişi), ihtiyaçlarının ön planda olduğu görülmektedir. Gençlerin birey olma yolunda önem verdikleri bir husus olan toplumsal statü kazanma, diğerlerinin ilgisini çekmek ve başarma ihtiyacı gelişim özelliklerini yansıtmaktadır. Ayrıca yine bu dönemin özelliği olarak bir gruba ait olma, o grubun bir üyesi olma isteği de ağır basmaktadır. Diğerlerinin ilgisini çekmek ve sevgisini kazanmak gençlik döneminde karşılanması gereken önemli ihtiyaçlardandır. Çalışmamızda ortaya çıkan sonuçlara bakıldığında ağır basan psikolojik ihtiyaçların gençlerin gelişim ödevleriyle örtüştügü görülmektedir. 


\section{Kaynakça}

Atkinson, J. W. (1957). Motivational determinants of risk-taking behavior. Psychological Review, 64, 359-372.

Auerbachand, C. F. ve Silverstein, L. B. (2003). Qualitative data. An Introduction to Coding and Analysis. New York: New York University Press.

Avc1, A., Bozgeyikli, H. ve Kesici, Ş. (2017). Psychological Needs as the Predictor of Teachers' Perceived Stress Levels. Journal of Education and Training Studies, 5(4), 154-164.

Aziz, A. (1994). Araştırma yöntemleri-teknikleri ve iletişim. Ankara: Turhan Kitabevi.

Baumeister, R. F. ve Leary, M. R. (1995). The need to belong: Desire for interpersonal attachments as a fundamental human motivation. Psychological Bulletin, 117, 497-529.

Bozgeyikli, H. (2010). The relationship between high school students' psychological needs and human value perceptions. Procedia Social and Behavioral Sciences 9, 1798-1804.

Brenning, K. ve Soenens, B. (2017). A Self-determination theory perspective on postpartum depressive symptoms and early parenting behaviors. Journal of Clinical Psychology, 73(12), 1729-1743.

Brott, P. E, ve Myers, J. E. (2002). Development of professional school counselor identity a grounded theory. (Edt. S. B., Merriam et al.). In Qualitative research in practice examples for discussion and analysis San Francisco: Jossey-Bass A Wiley Company, pp. 145-160.

Buhrmester, D. (1990). Intimacy of friendship, interpersonal competence, and adjustment during preadolescence and adolescence. Child Development, 61, 1101-1111.

Büyüköztürk, Ş., Kılıç-Çakmak, E., Akgün, Ö. E., Karadeniz, Ş., Demirel, F. (2008). Bilimsel araştırma yöntemleri (2.Bask1). Ankara: Pegem Akademi.

Can, G. (2009). Eğitim psikolojisi (Edt. Binnur Yeşilyaprak) (5.Baskı). Ankara: Pegem Akademi.

Ceylan, T. (2011). Toplumsal sistem analizinde toplumsal statü ve rol. Atatürk Üniversitesi Sosyal Bilimler Enstitüsü Dergisi, 15 (1), 89-104. 
Csikszentmihalyi, M. (1990). Flow: The psychology of optimal experience. New York: Harper Perennial.

Deci, E. L. ve Ryan, R. M. (2008). Facilitating Optimal Motivation and Psychological WellBeing Across Life's Domains. Canadian Psycho$\log y, 49(1), 14-23$.

Deci, E. L., Ryan, R. M., Gagné, M., Leone, D. R., Usitnov, J., ve Kornazheva, B. P. (2001). Need satisfaction, motivation, and well-being in the work organizations of a former eastern bloc country. Personality and Social Psychology Bulletin, 27, 930-942.

Deci, E. L. ve Vansteenkiste, M. (2004). Selfdetermination theory and basic need satisfaction: Understanding human development in positive psychology. Ricerche di Psicologia, 27, 23-40.

Doğan, S. ve Kesici, Ş. (2015). Üstün yetenekli öğrencilerin psikolojik ihtiyaçlarının bazı değişkenlere göre incelenmesi. Türkiye Sosyal Politika ve Çalışma Hayatı Araştırmaları Dergisi, 5(8), 45-81.

Ekiz, D. (2017). Bilimsel araştırma yöntemleri (5.baskı). Ankara: Anı Yayıncllik.

Erden, M. ve Akman, Y. (2004). Gelişim ve öğrenme (13.Baskı). Ankara: Arkadaş Yayınevi.

Erikson, E. H. (1968) Identity: Youth and crisis. New York: Norton.

Erikson, E. H. (1977). Childhood and society. London: Paladin Grafton Books.

Erwin, J. C. (2003). Giving students what they need. Educational Leadership, 61(1), 19-23.

Filak, V. F., ve Sheldon, K. M. (2003). Student psychological need satisfaction and college teacher-course evaluations. Educational Psychology, 23(3), 235-247.

Güngör, A. (2006). Gelişim ve öğrenme (Edt.Ayten Ulusoy). Ankara:Anı Yayıncilik.

Güler, A., Halıcıoğlu, M. B. ve Taşğın, S. (2015). Sosyal bilimlerde nitel araştırma (2.Baskı). Ankara: Seçkin Yayıncılık.

İstanbul Büyükşehir Belediyesi APK Daire Başkanlığı Araştırma Müdürlüğü (2004). Sosyal Doku Projesi Araştırmaları-3-Gençlik, İstanbul: Gökçe Ofset. 
Jang, H., Reeve, J., Ryan, R. M. ve Kim, A. (2009). Can self-determination theory explain what underlies the productive, satisfying learning experiences of collectivistically oriented Korean students? Journal of Educational Psychology, 101(3), 644-661.

Kesici, Ş. (2007). Şube rehber öğretmenlerinin görüşlerine göre 6. 7. ve 8.sınıf öğrencilerinin rehberlik ve danışma ihtiyaçları, Selçuk Üniversitesi Sosyal Bilimler Enstitüsü Dergisi, 17, 365-383.

Kesici, Ş. (2008a).Yeni psikolojik ihtiyaç değerlendirme ölçeğinin türkçe formunun geçerlik ve güvenirlik çalışması: doğrulayıcı faktör analizi sonuçları. Selçuk Üniversitesi Sosyal Bilimler Enstitüsü Dergisi, 20, 493-500.

Kesici, Ş. (2008b). Sixth-, seventh, and eighth-grade students' guidance and counseling needs according to parents' views. Eurasian Journal of Educational Research, 32, 101-116.

Kesici, S. (2015). Psychological needs as predictors of human values in high school students, The Anthropologist, 19(2), 499-506.

Kowal, J. ve Fortier, M. (1999). Motivational determinants of flow: Contributions from self-determination theory. Journal of Social Psychology, 139 (3), 355-369.

Lacey A. ve Luff, D. (2007). Qualitative research analysis. East Midlands / Yorkshire \& the Humber: The NIHR RDS.

Larson, R. (2006). Positive youth development, willful adolescents, and mentoring. Journal of Community Psychology, 34 (6), 677-689.

Litwack, L. (2007). Basic needs, a retrospective. International Journal of Reality Therap, 24(2), 28-30.

Maslow, A. H. (1954). Motivation and personality. New York: Harper \& Row.

Maslow, A. H. (1968). Toward a psychology of being (Second Edition). New York :Van Nostrand Reinhold.

McClelland, D. C., Atkinson, J. W., Clark, R. A., ve Lowell, E. L. (1953). The achievement motive. New York: Appleton-Century-Crofts.

McClelland, D.C. (1985). Human motivation. NY: Cambridge University Press.

McLeod, J. (2000). Media and civic socialization of youth. Journal of Adolescent Health, 27, 45-51. 
Miles, M. B., Huberman, A. M. (1994). Qualitative data analysis. India: SAGE Publications.

Murray, H. A. (1938). Explorations in personality. New York: Oxford University Press.

Özkan, İ. (1987). Gençliğin akademik(okul) başarısını etkileyen zihinsel ve ruhsal faktörler. I. Milletlerarası Gençlik Kongresi. 26-28 Ekim, Konya, Türkiye.

Ryan, R. M., ve Deci, E. L. (2000). Self-determination theory and the facilitation of intrinsic motivation, social development, and wellbeing. American Psychologist, 55, 68-78.

Ryan, R. M. ve Deci, E. L. (2006). Self-regulation and the problem of human autonomy: Does psychology need choice, selfdetermination, and will? Journal of Personality, 74(6), 1557-1586.

Sagie,A., ve Elizur,D.(1999). Achievement motive and entrepreneurial orientation: a structural analysis. Journal of Organizational Behavior, 20, 375-387.

Senemoğlu, N. (2005). Gelişim öğrenme ve öğretim. Ankara: Gazi Kitabevi.

Sheldon, K. M., Ryan, R. M., Deci, E. L., ve Kasser, T. (2004). The independent effects of goal contents and motives on well-being: It's both what you pursue and why you pursue it. Personality and Social Psychology Bulletin, 30, 475-486.

Strickland, B. R. (2001). The Gale encyclopedia of psychology (Second Edition). United States of America: Gale Group.

Tavşancıl, E. ve Aslan, E. (2001). Sözel yazılı ve diğer materyaller için içerik analizi ve uygulama örnekleri. İstanbul: Epsilon Yayınları.

Tuncay, S. (2000). Türkiye' de gençlik sorunlarının psikolojik boyutu. Muğla Üniversitesi SBS Dergisi, 1, 244-251.

Vlachopoulos, S. P. ve Michailidou, S. (2006). Development and initial validation of a measure of autonomy, competence, and relatedness in exercise: The basic psychological needs in exercise scale. Measurement in Physical Education and Exercise Science, 103, 179201.

Yıldırım, A. ve Şimşek, H. (2005). Sosyal bilimlerde nitel araştırma yöntemleri. Ankara: Seçkin Yayıncılık.

Young, J.E., Klosko, J.S. ve Weishaar, M.E. (2003). Schema Therapy: A Practitioner's Guide. New York: Guilford Press. 


\section{Kaynakça Bilgisi / Citation Information}

Girgin-Büyükbayraktar, Ç., Bozgeyikli, H. ve Kesici, Ş. (2018). Gençlerin psikolojik ihtiyaçları nelerdir?. OPUS - Uluslararası Toplum Araştırmaları Dergisi, 8(Gençlik Araştırmaları Özel Sayısı), 11-26. 